\title{
Exercise and diabetes: relevance and causes for response variability
}

\author{
Anja Böhm ${ }^{1,2,3} \cdot$ Cora Weigert $^{1,2,3} \cdot$ Harald Staiger ${ }^{1,2,3} \cdot$ Hans-Ulrich Häring ${ }^{1,2,3}$
}

Received: 10 September 2015/ Accepted: 28 October 2015/Published online: 7 December 2015

(C) The Author(s) 2015. This article is published with open access at Springerlink.com

\begin{abstract}
Exercise as a key prevention strategy for diabetes and obesity is commonly accepted and recommended throughout the world. Unfortunately, not all individuals profit to the same extent, some exhibit exercise resistance. This phenomenon of non-response to exercise is found for several endpoints, including glucose tolerance and insulin sensitivity. Since these non-responders are of notable quantity, there is the need to understand the underlying mechanisms and to identify predictors of response. This displays the basis to develop personalized training intervention regimes. In this review, we summarize the current knowledge on response variability, with focus on human studies and improvement of glucose homeostasis as outcome.
\end{abstract}

Keywords Non-response - Adverse response to exercise . Lifestyle intervention - Exercise resistance - Insulin sensitivity · Glucose homeostasis - Glucose tolerance

Hans-Ulrich Häring

hans-ulrich.haering@med.uni-tuebingen.de

1 Department of Internal Medicine IV, Division of Endocrinology, Diabetology, Angiology, Nephrology, and Clinical Chemistry, University Hospital Tübingen, Eberhard Karls University Tübingen, 72076 Tübingen, Germany

2 Institute for Diabetes Research and Metabolic Diseases of the Helmholtz Center Munich at the Eberhard Karls University Tübingen, Tübingen, Germany

3 German Center for Diabetes Research (DZD), 85764 München-Neuherberg, Germany

\section{Introduction}

The global epidemic of type 2 diabetes burdens humankind. The WHO projects that diabetes will be the 7th leading cause of death in 2030. For prevention, healthy diet as well as achievement and maintenance of normal body weight are recommended. Furthermore, at least $30 \mathrm{~min}$ of regular, moderate-intense physical activity five times a week is required [1,2]. Nevertheless, our strategies to prevent type 2 diabetes are still insufficient; since decades, a major purpose of research is to develop reasonable prevention strategies and to specify detailed pathomechanisms leading to diabetes.

There are myriads of intervention studies dealing with the best exercise type, frequency, intensity, and duration, further sophisticated by additional diets [3-20 and many more], and the scientific discussion is still ongoing. Indeed, positive effects of regularly performed exercise on cardiorespiratory fitness and metabolic control are without dispute. In most of the well-known diabetes prevention studies as DPS, DDP, HERITAGE, LookAHEAD, STRRIDE, Da Qing Diabetes Study, TULIP, and others, the risk reduction for diabetes, the metabolic syndrome or cardiovascular events ranges around $35 \%$ [4, 21-35]. Despite this knowledge, less than $40 \%$ of European countries developed national recommendations for physical activity [36].

\section{Response variability}

Most of the conducted studies found not only improvements in metabolic and cardiorespiratory endpoints after training intervention, but also highly variable inter-individual responses [37-39]. Maximum oxygen uptake $\left(\mathrm{VO}_{2} \mathrm{max}\right)$ is the standard parameter of cardiorespiratory fitness and is widely used to document the effectiveness of training. The 
HERITAGE trial identified low responders and high responders for improvements of $\mathrm{VO}_{2} \max$ [40]. A similar variability for glucose homeostasis, reflected by insulin sensitivity, acute insulin response, glucose effectiveness, and glucose disappearance index was shown [41]. The general distribution of individual changes seems to have a twosided shape, ranging from high responders to even adverse responders that show a deterioration of the respective endpoint. Notably, the term "non-response to exercise" always needs a clear association with a specific endpoint. It is used with respect to changes in several, different parameters assessed before and after training, e.g., fitness, cardiovascular events, muscle mass, metabolic risk profiles, lipid metabolism, insulin resistance, glucose tolerance, and others. In this review, we focus on the failure to improve wholebody glucose homeostasis after training interventions in humans. Physical activity is often included in lifestyle intervention programs combining dietary regimes with exercise, and sometimes we also refer to data based on lifestyle intervention. Since it is not possible to differentiate between exercise-dependent and exercise-independent effects in these studies, this is always clearly stated.

What about the quantity of these non-, low-, or even adverse responders? As recently reviewed [42], the number of adverse responders with respect to fasting insulin including six exercise training studies (HERITAGE, DREW, INFLAME, STRRIDE, MARYLAND, and JYVASKYLA) averaged $8.3 \%$. Non-response defined as no improvement regarding glucose homeostasis, leads to 7-63\% non-responders [41, 43-49]. For further details, see Table 1 . Most of the conducted studies are performed without a control group. Thus, the opinion exists that exercise might cause adverse metabolic effects for some individuals. However, a study performed with 87 participants including a control group [45], demonstrated clearly a decreased number of an adverse response (41\%) versus $76 \%$ in control group; the adverse response was defined as increased fasting glucose, 2 -h glucose, and triglycerides, as well as a decrease for HDL-cholesterol.

Notably, the failure to improve one metabolic factor is not necessarily reflected by a non-response in other variables, e.g., $\mathrm{VO}_{2} \mathrm{max}$, and vice versa [50]. Although there is a clear positive correlation of $\mathrm{VO}_{2} \max$ and insulin sensitivity in the general population [51-53] and an increase in $\mathrm{VO}_{2} \max$ correlates with the improvement in glucose homeostasis [54] and insulin sensitivity [55] in large lifestyle intervention programs, this is not true for each individual. In 202 diabetic individuals of the HART-D study, only $37 \%$ had a marked increase in $\mathrm{VO}_{2} \mathrm{max}$, but all profited regarding metabolic parameters, irrespective of $\mathrm{VO}_{2} \max$ response [56]. Furthermore, metabolic fitness parameters like respiratory exchange ratio, maximal heart rate, and maximal ventilatory equivalent do not relate to changes in aerobic capacity [57].

Thus, despite a relevant exercise-related improvement of systolic blood pressure, body weight, $\mathrm{VO}_{2} \mathrm{max}$, lipid profile, etc., one may not have a beneficial effect on

Table 1 Quantity of non-responders

\begin{tabular}{|c|c|c|c|c|c|}
\hline Citation & Population & Intervention & Duration & Outcome & $\begin{array}{l}\text { Non-responders } \\
(\%)^{\mathrm{a}}\end{array}$ \\
\hline Boulé [41] & $n=596$, healthy & $\begin{array}{l}\text { Endurance training, } 3 \times / \text { week, } \\
55-75 \% \mathrm{VO}_{2} \mathrm{max},\end{array}$ & 20 weeks & Insulin sensitivity & 42 \\
\hline Borel [46] & $\begin{array}{l}n=104, \\
\text { abdominally } \\
\text { obese/dyslipidemic }\end{array}$ & $\begin{array}{l}160 \mathrm{~min} / \text { week moderate- } \\
\text { intensity exercise and } \\
-500 \mathrm{kcal} \text { per day, } \\
\text { pedometer use }\end{array}$ & 12 months & Glucose tolerance status & 62.5 \\
\hline Hagberg [49] & $n=110$, healthy & $\begin{array}{l}\text { endurance training, } 3 \times / \text { week, } \\
50-70 \% \mathrm{VO}_{2} \max \end{array}$ & 26 weeks & Insulin sensitivity & 25 \\
\hline Yates [45] & $n=29$, prediabetic & $\begin{array}{l}\text { education program with } \\
\text { pedometer use }\end{array}$ & 12 months & 2-h glucose & $7^{\mathrm{b}}$ \\
\hline Winett [44] & $n=159$, prediabetic & Resistance training, $2 \times /$ week & 3 months & 2-h OGTT & $44^{\mathrm{c}}$ \\
\hline Stephens [48] & $n=42$, diabetic & $\begin{array}{l}\text { Aerobic, resistance training, or } \\
\text { combination thereof }\end{array}$ & 9 months & $\begin{array}{l}\text { Combination of } \\
\text { HbA1c, \% body fat, } \\
\text { BMI, muscle } \\
\text { mitochondrial content }\end{array}$ & 21 \\
\hline Osler [47] & $n=14$, prediabetic & $\begin{array}{l}\text { Nordic walking, } 5 \mathrm{~h} / \text { week, } \\
\text { unsupervised }\end{array}$ & 20 weeks & Glucose tolerance status & 36 \\
\hline
\end{tabular}

Quantity of non-responders with respect to glucose homeostasis

a Meaning no improvement, unless stated otherwise

b Adverse response

c Estimated from graph 
glucose homeostasis; this adds even more complexity to this issue.

It is still under debate [11, 16, 42, 43, 58-62], which training intervention is the best, and this will not be in focus of this review. However, a recent study gave hint for a combination of low-amount/vigorous-intensity aerobic exercise and resistance training being favored [63]. Highintensity interval training has been practiced by athletes for some time [64]; recently it receives much interest as promising part of lifestyle intervention programs [65]. It can be superior to moderate-intense, time-consuming continuous training in improving cardiorespiratory fitness [66], and beneficial effects on glucose homeostasis or insulin sensitivity have been shown after just short training duration $[67,68]$. If high-intensity interval training will be advantageous, and which subpopulation is suitable to that, we will learn from future randomized, controlled studies. Additionally, the question arises, if the highly individual responses to exercise might be overcome by different training regimes.

To sum up, individual exercise response is known for several years now $[11,37,57,69,70]$, but shifting the focus on non-response in terms of glucose homeostasis is just beginning [29, 43, 46-48, 56, 71, 72].

\section{Prediction of and mechanisms for failure}

Understanding and defining the individual susceptibility for non-response will be a major purpose in the future. This is the basis for the development of personalized training strategies to prevent and treat type 2 diabetes. Regarding success-predictive baseline values, our knowledge is limited to few studies and endpoints, as reviewed by [73], and the results are partly complementary. Of course, personal adherence to lifestyle intervention is a major fundament for success [74]; thus, exercise studies should exclusively be supervised.

Beyond this, in the HERITAGE study, baseline values were found to account for $\sim 40 \%$ variability in trainingrelated changes; but only for some traits, such as submaximal heart rate and blood pressure, where high baseline levels were associated with major exercise-driven improvements [37]; but not for baseline $\mathrm{VO}_{2} \mathrm{max}$, HDL, age, nor for sex and race [39], where no relationships were found; contrarily, age was mentioned as a relevant variable in dose-responsiveness to exercise [75], as older adults might require higher doses of training. Another study showed, that there are no non-responders in elderly practicing a prolonged resistance training [60]. Notably, insulin sensitivity or glucose tolerance was not among the endpoints of this study [60]. Additionally, women with low fitness at baseline were shown to have greater exerciserelated fitness improvements [76].
For glucose homeostasis, there are quite little data. Risk factors for non-response are speculated, but far from being comprehensively understood. But recognizing these individuals that fail to profit from exercise is of major importance. In a 9 months exercise study, long duration of type 2 diabetes and increases in serum free fatty acids (FFA) were positively associated with $\mathrm{HbA} 1 \mathrm{c}$ changes, whereas serum adiponectin levels and muscle protein content of peroxisome proliferator-activated receptor $\gamma$ coactivator $1 \alpha$ (PGC1 $\alpha$ ) correlated inversely with changes in HbA1c [77]. In plasma, reduction of ceramides was correlated with exercise-related improvements in insulin sensitivity [78]. A whole blood gene expression analysis after 12 weeks of lifestyle intervention in Latino adolescents showed upregulated genes, e.g., for insulin signaling, glucose uptake, and glycogen storage as well as down-regulation of genes involved in inflammatory pathways, and the analysis exhibited five times the number of regulated transcripts in insulin sensitivity- responders compared to non-responders in terms of insulin sensitivity [79]. This might point to a reduced adaption to training stress in non-responders. From the Diabetes Prevention Program, we know that low insulin secretion and low insulin sensitivity at baseline generally predict higher diabetes risk regardless of the treatment regime [80]. Our own data from the TULIP study showed low insulin secretion and sensitivity, low cardiorespiratory fitness, high liver and visceral fat, as well as high fetuin A predictive for non-response regarding glucose homeostasis [55, 72, 81, 82], whereas age, sex, and BMI at baseline were not predictive. Notably, this was a lifestyle intervention study, and conclusions on exercise-specific changes can only be speculated. Indeed, exercise-driven improvement of glucose tolerance was only shown in insulin-resistant individuals with adequate insulin secretion [83].

Thus, there are several pathomechanisms conceivable leading to failed exercise-related improvement of glucose homeostasis: most expectedly, no improvement in insulin sensitivity with consequences in all insulin-responsive tissues (muscle, adipose tissue, liver, brain) leads to less glucose deposition and increased endogenous glucose production; furthermore, less insulin secretion or altered glucose/fatty acid metabolism could be pathogenic. Presumably, the non-response regarding glucose homeostasis might be a combination of these factors, and distinguishing this will be very sophisticated.

Is worse glucose homeostasis per se objectively a risk factor for non-response? There is some evidence given by several exercises [45, 84-86] and lifestyle intervention studies [29, 46, 87] that individuals with higher metabolic burden seem to profit more. Contrarily, in another study, responders in terms of glucose tolerance had better glucose homeostasis values at the beginning than non-responders 
[47]; additionally, women at lower genetic risk for obesity (calculated by a risk score dependent on 21 SNPs associated with BMI variation) showed more favorable responses regarding resistance training-associated changes of body fat composition [88]. These partly conflicting results might be explained by a ceiling-effect for some variables, different populations and study settings. Alternatively, there might be a threshold in any metabolic parameter-perhaps insulin secretion?-beyond which the benefit suddenly converts to the opposite. Until now, there is too much speculation on pathomechanisms and we clearly require further studies in well-defined populations under controlled conditions for better characterization of responders and non-responders.

\section{Genetic aspects of non-response}

Already in the 1980s, the relevance of heredity in exerciseinduced adaptations was shown [89]. For exercise-related improvements of $\mathrm{VO}_{2} \mathrm{max}$, the heritability is reported to be about $47 \%$ [40, 90]. Single nucleotide polymorphisms (SNPs) are found to play a role in the training-induced changes in $\mathrm{VO}_{2} \max$ [91]; also for the endpoint muscle strength this was shown [92]. A combination of several SNPs contributes to $\sim 50 \%$ of the inter-individual variance in changes of $\mathrm{VO}_{2} \max [93,94]$, pointing to a multifactorial inheritance of general non-response. A genetic variant in NDUFB6, encoding for complex I of the respiratory chain, can modify the individual response of the ATP synthase flux, even independently from exercise-related improvements of insulin sensitivity [95]. For metabolic syndrome in general, risk allele carriers of IL6R had more profit from a lifestyle modification including diet and exercise [96]. In genome-wide linkage-scans, a genomic region close to the leptin locus emerged to contribute to the fasting insulin response to exercise training [97]. And in 180 Brazilians, an FTO polymorphism was associated with decreased fasting plasma glucose after 9-month lifestyle intervention [98]. Additionally, polymorphisms in ADIPOR1 [99], PPARG [49], PPARD [100], PPARGC1A (encoding PGC1 $\alpha$ ) [101], TCF7L2 [102], and SIRT1 [103] were shown to impact the glucose homeostasis response to lifestyle intervention [71].

Exercise also regulates epigenetic modifications [104], in CpG-islands [105], enhancer sites [106, 107], as well as on histones [108]; furthermore, micro-RNA expression changes due to exercise were shown, in plasma [109] and skeletal muscle [110]. There is evidence that different doses of exercise reveal different inflammatory miRNA responses [111]. Notably, insulin sensitivity might influence the epigenetic response to exercise [112]. But investigating the relevance of differences in epigenetic regulation for the variability in exercise response has just started. One study reported highly variable responses in muscle mass upon resistance training and deciphers differentially expressed microRNAs [113].

Impact and interplay of genetic factors for non-response will be specified in the future. Additionally, whether the genetic influence might be overcome by higher training intensities/volumes/types is not clear yet and requires future research.

\section{Muscle}

Skeletal muscle displays one of the most important target tissues of insulin. It accounts for more than $85 \%$ of insulin-dependent glucose uptake [114]; thus, mechanistic studies to elucidate the metabolic adaptation to exercise and its regulation mostly focus on skeletal muscle. The training-induced improvement in glucose disposal has been attributed among other non-muscle adaptations to increases in muscle mass, muscle fiber type switching, mitochondrial biogenesis, and enhanced capillarization [115-117]. On a molecular level, increased abundance and altered posttranslational modifications of proteins important in uptake and oxidation of glucose and fatty acids have been shown [118-121]. Together, enhanced fuel oxidation in muscle appears to be one major key mechanism of improved glucose control after training [24].

Given the relevance of oxidative metabolism in the prevention of poor glucose homeostasis, it was speculated that differences in mitochondrial content and mitochondrial fuel oxidation in response to training might play a role in exercise non-response [43]. In a subgroup of the HART-D study, non-responders were defined as diabetic individuals with constant $\mathrm{HbA1c}$, percent body fat, and BMI, and reduced muscle mitochondria content after exercise [48]. A microarray analysis of muscle biopsies of these non-responders at baseline revealed 186 differentially regulated mRNAs compared with responders, mostly affecting substrate metabolism and mitochondrial biogenesis/function [48]. Increased mRNA levels of genes encoding for mitochondrial proteins were also found in prediabetic responders versus non-responders in terms of glucose tolerance [47]. Higher muscle concentrations of the tricarboxylic acid cycle intermediates were found to correlate best with exercised-induced change in insulin sensitivity [63], at least in a vigorous-intensity exercise group. In 66 untrained participants of a resistance training intervention, a proinflammatory transcript profile was associated with the failure to induce muscle hypertrophy, whereas genes involved in muscle development were uniquely expressed in responders regarding myofiber hypertrophy at baseline [122].

To conclude, the data on specific adaptations in the muscle of responders and non-responders highlight the 
relevance of mitochondrial pathways for the improvement of metabolic control, independent of different biopsy timings, training regimes, heterogeneous cohorts, and different definitions of metabolic non-response among studies. Notably, for detailed pathomechanisms, we have to differentiate thoroughly between mitochondrial content, OXPHOS capacity, and fat oxidation. An important issue here is to understand the individual variability in these mitochondrial adaptations and the molecular basis for the susceptibility to resist to training intervention.

\section{Adipose tissue}

Adipose tissue contributes relevantly to whole-body metabolism, both as metabolic sink and an endocrine organ $[123,124]$. Notably, being obese implies a greater risk for development of type 2 diabetes than being inactive [125]. Improvement of glucose homeostasis after 1 year of combined lifestyle intervention in 104 viscerally obese men was not independently associated with improvement of cardiorespiratory fitness, but with changes in visceral and subcutaneous adipose tissue [46]. Thus, beneficial metabolic improvements seem to be mediated by adipose tissue $[46,72,126,127]$. That is in line with an observation that there are no weight-independent exercise effects on adipokines [128]. Recent studies in mice affirmed a role for subcutaneous adipose tissue in exercise-induced improvements in glucose homeostasis [129, 130]. On the other hand, anti-inflammatory effects of exercise on adipose tissue are reported to be weight-loss-independent [131].

Effects of exercise affect all fat compartments. General exercise-related changes on adipose tissue comprise fat loss per se, beneficial shifts in body fat composition, altered mitochondrial function, and secretory responses [125, 131-134]. It seems to be established that exercise leads to increased subcutaneous adiponectin mRNA levels, while other adipokines and their systemic relevance are under discussion [132]. In a 6-month supervised exercise intervention in 47 healthy sedentary men [135], genes encoding the respiratory chain, histone subunits, small nucleolar RNAs, ribosomal proteins, and pathways like oxidative phosphorylation were up-regulated, whereas Wnt and mitogen-activated protein kinase (MAPK) signaling pathways were down-regulated due to exercise.

Elevated adipose tissue peroxisome proliferator-activated receptor gamma (PPARg) and PGC1 $\alpha$ were early supposed to mediate the beneficial effects of exercise on insulin sensitivity [136]. Also suppressed angiogenesis in white adipose tissue after exercise was associated with insulin resistance [137]. Additionally, endothelial nitric oxide synthase (eNOS) seems to be a major control point in the fragile energy metabolism balance [133], as it gained attention as an inductor of mitochondrial biogenesis [138].
Conversion of white adipocytes to more energy-dissipating brown-like adipocytes is known as browning. This effect might also play a role in adipocytes' response to exercise [139]. There is further evidence that high physical activity leads to increased brown adipose tissue activity [140]. If browning in humans is of relevant impact, is currently under discussion [141-143]. In this respect, the role of a PGC- $1 \alpha$-dependent exercise-induced myokine and browning factor identified in mice [144], named irisin, was recently very controversially discussed in humans [145$148]$.

In conclusion, there is good evidence that not only muscle, but also altered adipose tissue metabolism can contribute to non-response.

\section{Liver}

Long-term lifestyle intervention leads to the reduction of intrahepatic lipids [29, 72, 149-151]; this reduction in liver fat mediates a relevant part of the beneficial effects on insulin resistance, more than reduction of other fat compartments does [72]. Furthermore, we and others have shown that liver fat is the most reactive fat compartment in response to a lifestyle intervention [72, 152]. Notably, after $2 \mathrm{~h}$ of aerobic exercise, intrahepatic lipids in 18 healthy lean volunteers increased about $35 \%$ from baseline, pointing to intrahepatic lipids as a very flexible fuel store [153] serving as a buffer for excess free fatty acids. Data on molecular alterations in the liver upon exercise are very limited, but exercise studies in mice gave hint for a pronounced regulation of signal transduction and gene expression in the liver [154, 155]. Recent data obtained from liver vein samples verified the hepatic release of FGF21 during exercise in humans [156]. This exercisedependent regulation of FGF21, a liver-derived factor with possibly beneficial effects on glucose control and body weight regulation [157], opens a further perspective for the individual regulation of exercise response on the level of hepatokines.

\section{Brain}

Exercise enhances functional brain capabilities [158]. Furthermore, exercise was shown to improve whole-body metabolism via the regulation of central control mechanisms: reduced appetite and food intake were reported $[159,160]$.

Vice versa, high-cerebral insulin sensitivity in humans at baseline was associated with higher loss of body fat during lifestyle intervention [161]. Unfortunately, the cohort was too small to find direct effects on glucose homeostasis, independent of fat loss. Since cerebral insulin sensitivity was found to affect peripheral insulin sensitivity 
$[162,163]$ and other brain functions as reviewed in [164], it is conceivable that individual differences of central insulin action are relevant for the response variability to exercise on glucose homeostasis. For further understanding of the exercise-brain-metabolism axis, we will need more human studies.

\section{Inflammation}

A role of subclinical inflammation in the development of obesity and diabetes is widely accepted. This linkage between inflammation and diabetes was extensively shown in various organs, like adipose tissue [165], skeletal muscle [166], and liver [167]. As the issue is very complex, and most of the molecules have both pro- and anti-inflammatory effects, the relevance of exercise-regulated cytokines and chemokines for the prevention or treatment of metabolic diseases is still under debate. Exercise-induced beneficial effects on metabolic control have been linked to several cytokines and chemokines with known functions in inflammatory processes [166]. Additionally, anti-inflammatory influences of regular exercise have been shown in several studies [168, 169]. In brain, anti-inflammatory exercise effects were reported, at least in mice [170]. Thus, although exercise acutely can induce inflammatory processes, predominantly after an unadjusted work load and eccentric exercise [171], it can help to reduce subclinical inflammation in the long run.

For exercise non-response, a role of a differential regulation of pro-/and anti-inflammatory cytokines can only be speculated; recently, this was supposed for skeletal muscle [122].

\section{Conclusion}

In this review, we discussed individual responses to exercise training in terms of glucose homeostasis; current ideas for underlying pathomechanisms for the lack of improvement in humans were summarized, as illustrated in Fig. 1. In general, we should clearly encourage our patients to increase their physical activity. There are many aspects, e.g., socio-economic, quality of life etc., beyond specific metabolic endpoints, which are worth being an active individual. Nevertheless, personalized adjustments of exercise recommendations are inevitable, different training strategies for individual subgroups may be necessary. Despite the very complex issue (different endpoints, training types, nutrition, populations, highly individual participants, etc.), we hopefully will promote our knowledge to tackle the non-response. Therefore, we do need further studies to unravel detailed mechanisms for insufficient responses to exercise training. Thus, well-designed, supervised studies with an adequate number of participants and clearly defined conditions for non-response are demanded; for elucidation of non-responders' characteristics and possible pathomechanisms, we should perform pure training interventions in deeply phenotyped cohorts; without noise of additional diet interventions, that should be investigated separately. Novel studies should address the following questions: Who is the non-responder? What are risk factors for non-response? How can we predict the non-response with easy-to-use parameters? Which of several training regimes could overcome non-response? Is interval training the new winner? Is there a correlation of several metabolic endpoints? To what extent? And valid
Fig. 1 Hypothetical and observed contribution to exercise non-response with respect to glucose homeostasis. For details, see text

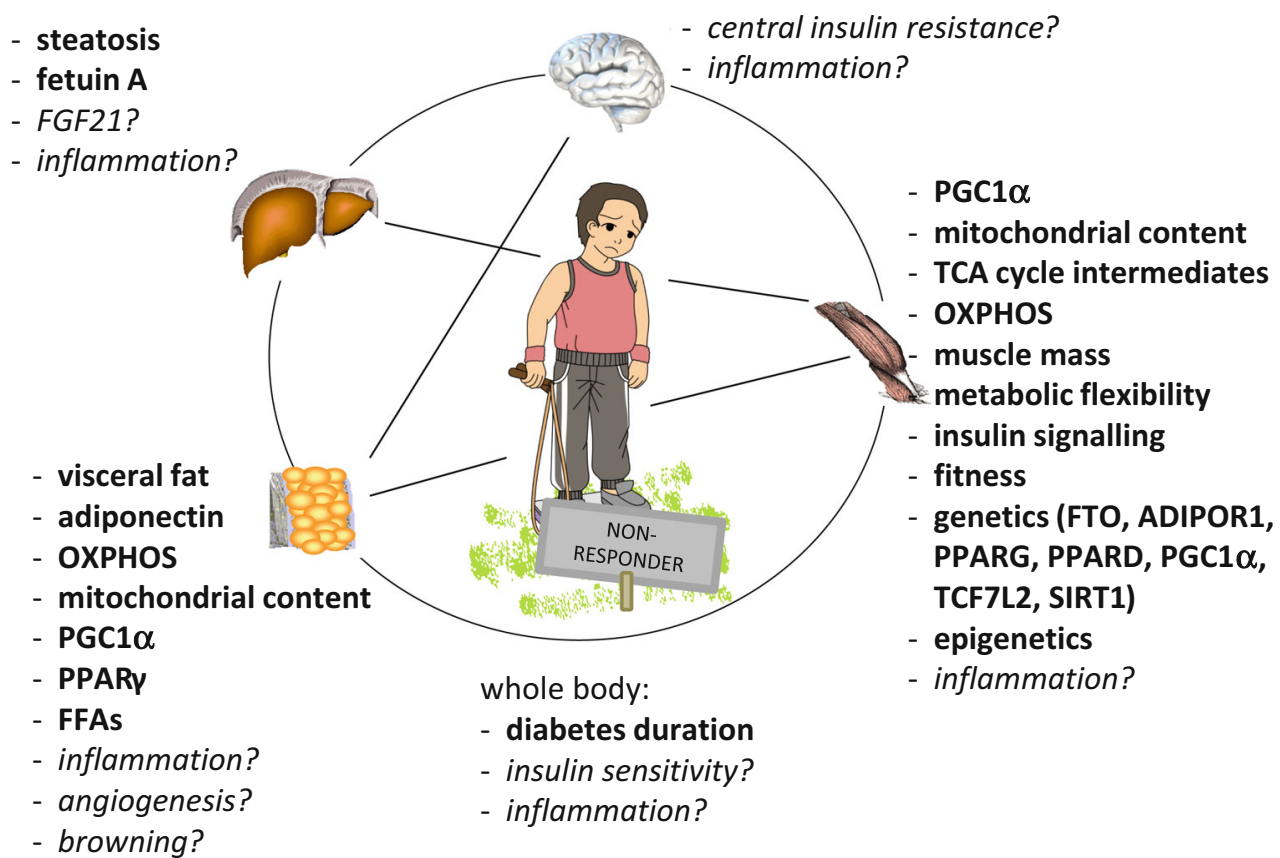


for every individual? What are the underlying molecular pathomechanisms for non-response? Are we able to discriminate discrete pathomechanisms, and what is their impact on whole-body glucose homeostasis?

More detailed, we need exact tissue-specific (using the biopsy technique) measurements, e.g., of mitochondrial content and function, and need to clarify a possible pathogenic role for inflammation. By omics-technology, we could drive new hypotheses, determining further mechanistic studies. Subsequently, this will hopefully generate novel ideas for a potential pharmacological treatment of non-response. Furthermore, with the modern technique of brain imaging available, we should specify the central-nervous influence on exercise non-response. It is mandatory to design supervised studies. There are myriads of large intervention studies showing benefits of exercise; thus, we should concentrate our efforts and funds on the above-mentioned questions. Last but not least, all our results should be feasible for our patients' daily routine far away from a controlled supervised study setting.

Disclosure There is nothing to disclose by the authors.

Open Access This article is distributed under the terms of the Creative Commons Attribution 4.0 International License (http://crea tivecommons.org/licenses/by/4.0/), which permits unrestricted use, distribution, and reproduction in any medium, provided you give appropriate credit to the original author(s) and the source, provide a link to the Creative Commons license, and indicate if changes were made.

\section{References}

1. C.D. Mathers, D. Loncar, Projections of global mortality and burden of disease from 2002 to 2030. PLoS Med. 3(11), e442 (2006)

2. WHO, WHOIGlobal recommendations on physical activity for health. WHO, 2010. [Online]. Available: http://www.who.int/ dietphysicalactivity/publications/9789241599979/en/. [Accessed: 15-Aug-2015]

3. C.-H. Lin, S.-L. Chiang, W.-C. Tzeng, L.-C. Chiang, Systematic review of impact of lifestyle-modification programs on metabolic risks and patient-reported outcomes in adults with metabolic syndrome. Worldviews Evid.-Based Nurs. Sigma Theta Tau Int. Honor Soc. Nurs. 11(6), 361-368 (2014)

4. D. Lee, C.J. Lavie, R. Vedanthan, Optimal dose of running for longevity: is more better or worse? J. Am. Coll. Cardiol. 65(5), 420-422 (2015)

5. D. Aune, T. Norat, M. Leitzmann, S. Tonstad, L.J. Vatten, Physical activity and the risk of type 2 diabetes: a systematic review and dose-response meta-analysis. Eur. J. Epidemiol. Jun. (2015)

6. J.E. Clark, Diet, exercise or diet with exercise: comparing the effectiveness of treatment options for weight-loss and changes in fitness for adults (18-65 years old) who are overfat, or obese; systematic review and meta-analysis. J. Diabetes Metab. Disord. 14, 31 (2015)

7. Z. Yang, C.A. Scott, C. Mao, J. Tang, A.J. Farmer, Resistance exercise versus aerobic exercise for type 2 diabetes: a systematic review and meta-analysis. Sports Med. Auckl. NZ 44(4), 487-499 (2014)

8. L. Schwingshackl, B. Missbach, S. Dias, J. König, G. Hoffmann, Impact of different training modalities on glycaemic control and blood lipids in patients with type 2 diabetes: a systematic review and network meta-analysis. Diabetologia 57(9), 1789-1797 (2014)

9. J.D. Taylor, J.P. Fletcher, R.A. Mathis, W.T. Cade, Effects of moderate- versus high-intensity exercise training on physical fitness and physical function in people with type 2 diabetes: a randomized clinical trial. Phys. Ther. 94(12), 1720-1730 (2014)

10. L. Chen, J.-H. Pei, J. Kuang, H.-M. Chen, Z. Chen, Z.-W. Li, H.Z. Yang, Effect of lifestyle intervention in patients with type 2 diabetes: a meta-analysis. Metabolism. 64(2), 338-347 (2015)

11. S. Bajpeyi, C.J. Tanner, C.A. Slentz, B.D. Duscha, J.S. McCartney, R.C. Hickner, W.E. Kraus, J.A. Houmard, Effect of exercise intensity and volume on persistence of insulin sensitivity during training cessation. J. Appl. Physiol. Bethesda Md 1985 106(4), 1079-1085 (2009)

12. L.M. Sparks, N.M. Johannsen, T.S. Church, C.P. Earnest, E. Moonen-Kornips, C. Moro, M.K.C. Hesselink, S.R. Smith, P. Schrauwen, Nine months of combined training improves ex vivo skeletal muscle metabolism in individuals with type 2 diabetes. J. Clin. Endocrinol. Metab. 98(4), 1694-1702 (2013)

13. T.S. Church, S.N. Blair, S. Cocreham, N. Johannsen, W. Johnson, K. Kramer, C.R. Mikus, V. Myers, M. Nauta, R.Q. Rodarte, L. Sparks, A. Thompson, C.P. Earnest, Effects of aerobic and resistance training on hemoglobin A1c levels in patients with type 2 diabetes: a randomized controlled trial. JAMA 304(20), 2253-2262 (2010)

14. J.A. Houmard, C.J. Tanner, C.A. Slentz, B.D. Duscha, J.S. McCartney, W.E. Kraus, Effect of the volume and intensity of exercise training on insulin sensitivity. J. Appl. Physiol. Bethesda Md 1985 96(1), 101-106 (2004)

15. S. Mann, C. Beedie, S. Balducci, S. Zanuso, J. Allgrove, F. Bertiato, A. Jimenez, Changes in insulin sensitivity in response to different modalities of exercise: a review of the evidence. Diabetes Metab. Res. Rev. 30(4), 257-268 (2014)

16. J. Li, W. Zhang, Q. Guo, X. Liu, Q. Zhang, R. Dong, H. Dou, J. Shi, J. Wang, D. Yu, Duration of exercise as a key determinant of improvement in insulin sensitivity in type 2 diabetes patients. Tohoku J. Exp. Med. 227(4), 289-296 (2012)

17. H.B. Simon, Exercise and health: dose and response, considering both ends of the curve. Am. J. Med. May (2015)

18. V. Sari-Sarraf, A. Aliasgarzadeh, M.-M. Naderali, H. Esmaeili, E.K. Naderali, A combined continuous and interval aerobic training improves metabolic syndrome risk factors in men. Int. J. Gen. Med. 8, 203-210 (2015)

19. T. Xiao, Y.-F. Fu, Resistance training vs. aerobic training and role of other factors on the exercise effects on visceral fat. Eur. Rev. Med. Pharmacol. Sci. 19(10), 1779-1784 (2015)

20. D. Hansen, P. Dendale, L.J.C. van Loon, R. Meeusen, The impact of training modalities on the clinical benefits of exercise intervention in patients with cardiovascular disease risk or type 2 diabetes mellitus. Sports Med. Auckl. NZ 40(11), 921-940 (2010)

21. X. Lin, X. Zhang, J. Guo, C.K. Roberts, S. McKenzie, W.-C. Wu, S. Liu, Y. Song, Effects of exercise training on cardiorespiratory fitness and biomarkers of cardiometabolic health: a systematic review and meta-analysis of randomized controlled trials. J. Am. Heart Assoc. 4(7) (2015)

22. G.R. Dutton, C.E. Lewis, The look AHEAD trial: implications for lifestyle intervention in Type 2 Diabetes mellitus. Prog. Cardiovasc. Dis. 58(1), 69-75 (2015)

23. Diabetes Prevention Program Research Group, W.C. Knowler, S.E. Fowler, R.F. Hamman, C.A. Christophi, H.J. Hoffman, A.T. 
Brenneman, J.O. Brown-Friday, R. Goldberg, E. Venditti, D.M. Nathan, 10-year follow-up of diabetes incidence and weight loss in the Diabetes Prevention Program Outcomes Study. Lancet Lond. Engl. 374(9702), 1677-1686 (2009)

24. C.K. Roberts, A.L. Hevener, R.J. Barnard, Metabolic syndrome and insulin resistance: underlying causes and modification by exercise training. Compr. Physiol. 3(1), 1-58 (2013)

25. T. J. Orchard, M. Temprosa, R. Goldberg, S. Haffner, R. Ratner, S. Marcovina, S. Fowler, Diabetes Prevention Program Research Group, The effect of metformin and intensive lifestyle intervention on the metabolic syndrome: the Diabetes Prevention Program randomized trial. Ann. Intern. Med. 142(8), 611-619 (2005)

26. P.T. Katzmarzyk, A.S. Leon, J.H. Wilmore, J.S. Skinner, D.C. Rao, T. Rankinen, C. Bouchard, Targeting the metabolic syndrome with exercise: evidence from the HERITAGE Family Study. Med. Sci. Sports Exerc. 35(10), 1703-1709 (2003)

27. J.L. Johnson, C.A. Slentz, J.A. Houmard, G.P. Samsa, B.D. Duscha, L.B. Aiken, J.S. McCartney, C.J. Tanner, W.E. Kraus, Exercise training amount and intensity effects on metabolic syndrome (from studies of a targeted risk reduction intervention through defined exercise). Am. J. Cardiol. 100(12), 1759-1766 (2007)

28. P. Ilanne-Parikka, D. E. Laaksonen, J. G. Eriksson, T. A. Lakka, J. Lindstr, M. Peltonen, S. Aunola, S. Keinánen-Kiukaanniemi, M. Uusitupa, J. Tuomilehto, Finnish Diabetes Prevention Study Group, Leisure-time physical activity and the metabolic syndrome in the Finnish diabetes prevention study. Diabetes Care 33(7), 1610-1617 (2010)

29. S. Schäfer, K. Kantartzis, J. Machann, C. Venter, A. Niess, F. Schick, F. Machicao, H.-U. Häring, A. Fritsche, N. Stefan, Lifestyle intervention in individuals with normal versus impaired glucose tolerance. Eur. J. Clin. Invest. 37(7), 535-543 (2007)

30. X.R. Pan, G.W. Li, Y.H. Hu, J.X. Wang, W.Y. Yang, Z.X. An, Z.X. Hu, J. Lin, J.Z. Xiao, H.B. Cao, P.A. Liu, X.G. Jiang, Y.Y. Jiang, J.P. Wang, H. Zheng, H. Zhang, P.H. Bennett, B.V. Howard, Effects of diet and exercise in preventing NIDDM in people with impaired glucose tolerance. the Da Qing IGT and diabetes study. Diabetes Care 20(4), 537-544 (1997)

31. N.G. Boulé, E. Haddad, G.P. Kenny, G.A. Wells, R.J. Sigal, Effects of exercise on glycemic control and body mass in type 2 diabetes mellitus: a meta-analysis of controlled clinical trials. JAMA 286(10), 1218-1227 (2001)

32. D.T. Lackland, J.H. Voeks, Metabolic syndrome and hypertension: regular exercise as part of lifestyle management. Curr. Hypertens. Rep. 16(11), 492 (2014)

33. H. AbouAssi, C.A. Slentz, C.R. Mikus, C.J. Tanner, L.A. Bateman, L.H. Willis, A.T. Shields, L.W. Piner, L.E. ElliottPenry, E.A. Kraus, K.M. Huffman, C.W. Bales, J.A. Houmard, W.E. Kraus, The effects of aerobic, resistance and combination training on insulin sensitivity and secretion in overweight adults from STRRIDE AT/RT: a randomized trial. J. Appl. Physiol. Bethesda Md 1985 jap.00509.2014, Apr. (2015)

34. C. Robertson, D. Archibald, A. Avenell, F. Douglas, P. Hoddinott, E. van Teijlingen, D. Boyers, F. Stewart, C. Boachie, E. Fioratou, D. Wilkins, T. Street, P. Carroll, C. Fowler, Systematic reviews of and integrated report on the quantitative, qualitative and economic evidence base for the management of obesity in men. Health Technol. Assess. Winch. Engl. 18(35), v-vi, xxiiixxix, 1-424 (2014)

35. J.A. Hawley, Exercise as a therapeutic intervention for the prevention and treatment of insulin resistance. Diabetes Metab. Res. Rev. 20(5), 383-393 (2004)

36. S. Kahlmeier, T.M.A. Wijnhoven, P. Alpiger, C. Schweizer, J. Breda, B.W. Martin, National physical activity recommendations: systematic overview and analysis of the situation in European countries. BMC Public Health 15, 133 (2015)

37. C. Bouchard, T. Rankinen, Individual differences in response to regular physical activity. Med. Sci. Sports Exerc. 33(6 Suppl), S446-S451; discussion S452-453, Jun. (2001)

38. D. Prud'homme, C. Bouchard, C. Leblanc, F. Landry, E. Fontaine, Sensitivity of maximal aerobic power to training is genotype-dependent. Med. Sci. Sports Exerc. 16(5), 489-493, Oct. (1984)

39. J.S. Skinner, A. Jaskólski, A. Jaskólska, J. Krasnoff, J. Gagnon, A.S. Leon, D.C. Rao, J.H. Wilmore, C. Bouchard, HERITAGE Family Study, Age, sex, race, initial fitness, and response to training: the HERITAGE Family Study. J. Appl. Physiol. Bethesda Md 198590 (5), 1770-1776, May (2001)

40. C. Bouchard, P. An, T. Rice, J.S. Skinner, J.H. Wilmore, J. Gagnon, L. Pérusse, A.S. Leon, D.C. Rao, Familial aggregation of $\mathrm{VO}(2 \mathrm{max})$ response to exercise training: results from the HERITAGE Family Study. J. Appl. Physiol. Bethesda Md 1985 87(3), 1003-1008, Sep. (1999)

41. N. G. Boulé, S. J. Weisnagel, T. A. Lakka, A. Tremblay, R. N. Bergman, T. Rankinen, A. S. Leon, J. S. Skinner, J. H. Wilmore, D. C. Rao, C. Bouchard, HERITAGE Family Study, Effects of exercise training on glucose homeostasis: the HERITAGE family study. Diabetes Care 28(1), 108-114 (2005)

42. C. Bouchard, S.N. Blair, T.S. Church, C.P. Earnest, J.M. Hagberg, K. Häkkinen, N.T. Jenkins, L. Karavirta, W.E. Kraus, A.S. Leon, D.C. Rao, M.A. Sarzynski, J.S. Skinner, C.A. Slentz, T. Rankinen, Adverse metabolic response to regular exercise: is it a rare or common occurrence? PLoS ONE 7(5), e37887 (2012)

43. N.A. Stephens, L.M. Sparks, Resistance to the beneficial effects of exercise in type 2 diabetes: are some individuals programmed to fail? J. Clin. Endocrinol. Metab. 100(1), 43-52 (2015)

44. R.A. Winett, B.M. Davy, J. Savla, E.L. Marinik, S.G. Winett, M.E. Baugh, K.D. Flack, Using response variation to develop more effective, personalized behavioral medicine? evidence from the resist diabetes study. Transl. Behav. Med. 4(3), 333-338 (2014)

45. T. Yates, M.J. Davies, C. Edwardson, D.H. Bodicoat, S.J.H. Biddle, K. Khunti, Adverse responses and physical activity: secondary analysis of the PREPARE trial. Med. Sci. Sports Exerc. 46(8), 1617-1623 (2014)

46. A.-L. Borel, J.-A. Nazare, J. Smith, N. Alméras, A. Tremblay, J. Bergeron, P. Poirier, J.-P. Després, Improvement in insulin sensitivity following a 1-year lifestyle intervention program in viscerally obese men: contribution of abdominal adiposity. Metabolism. 61(2), 262-272 (2012)

47. M.E. Osler, T. Fritz, K. Caidahl, A. Krook, J.R. Zierath, H. Wallberg-Henriksson, Changes in gene expression in responders and nonresponders to a low-intensity walking intervention. Diabetes Care 38(6), 1154-1160 (2015)

48. N.A. Stephens, H. Xie, N.M. Johannsen, T.S. Church, S.R. Smith, L.M. Sparks, A transcriptional signature of 'exercise resistance' in skeletal muscle of individuals with type 2 diabetes mellitus. Metabolism. Jun. (2015)

49. J.M. Hagberg, N.T. Jenkins, E. Spangenburg, Exercise training, genetics and type 2 diabetes-related phenotypes. Acta Physiol. Oxf. Engl. 205(4), 456-471 (2012)

50. F. Scharhag-Rosenberger, S. Walitzek, W. Kindermann, T. Meyer, Differences in adaptations to 1 year of aerobic endurance training: individual patterns of nonresponse. Scand. J. Med. Sci. Sports 22(1), 113-118 (2012)

51. M. Rosenthal, W.L. Haskell, R. Solomon, A. Widstrom, G.M. Reaven, Demonstration of a relationship between level of physical training and insulin-stimulated glucose utilization in normal humans. Diabetes 32(5), 408-411 (1983) 
52. M. Wei, L.W. Gibbons, T.L. Mitchell, J.B. Kampert, C.D. Lee, S.N. Blair, The association between cardiorespiratory fitness and impaired fasting glucose and type 2 diabetes mellitus in men. Ann. Intern. Med. 130(2), 89-96 (1999)

53. T.P.J. Solomon, S.K. Malin, K. Karstoft, S.H. Knudsen, J.M. Haus, M.J. Laye, J.P. Kirwan, Association between cardiorespiratory fitness and the determinants of glycemic control across the entire glucose tolerance continuum. Diabetes Care 38(5), 921-929 (2015)

54. S. Balducci, S. Zanuso, P. Cardelli, L. Salvi, G. Mazzitelli, A. Bazuro, C. Iacobini, A. Nicolucci, G. Pugliese, Italian Diabetes Exercise Study (IDES) Investigators, Changes in physical fitness predict improvements in modifiable cardiovascular risk factors independently of body weight loss in subjects with type 2 diabetes participating in the Italian Diabetes and Exercise Study (IDES). Diabetes Care 35(6), 1347-1354, Jun. (2012)

55. C. Totsikas, J. Röhm, K. Kantartzis, C. Thamer, K. Rittig, J. Machann, F. Schick, J. Hansel, A. Niess, A. Fritsche, H.-U. Häring, N. Stefan, Cardiorespiratory fitness determines the reduction in blood pressure and insulin resistance during lifestyle intervention. J. Hypertens. 29(6), 1220-1227 (2011)

56. A. Pandey, D.L. Swift, D.K. McGuire, C.R. Ayers, I.J. Neeland, S.N. Blair, N. Johannsen, C.P. Earnest, J.D. Berry, T.S. Church, Metabolic effects of exercise training among fitness-nonresponsive patients with type 2 diabetes: the HART-D study. Diabetes Care 38(8), 1494-1501 (2015)

57. N.B.J. Vollaard, D. Constantin-Teodosiu, K. Fredriksson, O. Rooyackers, E. Jansson, P.L. Greenhaff, J.A. Timmons, C.J. Sundberg, Systematic analysis of adaptations in aerobic capacity and submaximal energy metabolism provides a unique insight into determinants of human aerobic performance. J. Appl. Physiol. Bethesda Md 1985 106(5), 1479-1486, May (2009)

58. L.A. Bateman, C.A. Slentz, L.H. Willis, A.T. Shields, L.W. Piner, C.W. Bales, J.A. Houmard, W.E. Kraus, Comparison of aerobic versus resistance exercise training effects on metabolic syndrome (from the studies of a targeted risk reduction intervention through defined exercise-STRRIDE-AT/RT). Am. J. Cardiol. 108(6), 838-844 (2011)

59. C.A. Slentz, J.A. Houmard, W.E. Kraus, Exercise, abdominal obesity, skeletal muscle, and metabolic risk: evidence for a dose response. Obes. Silver Spring Md 17(Suppl 3), S27-33 (2009)

60. T.A. Churchward-Venne, M. Tieland, L.B. Verdijk, M. Leenders, M.L. Dirks, L.C.P.G.M. de Groot, L.J.C. van Loon, There are no nonresponders to resistance-type exercise training in older men and women. J. Am. Med. Dir. Assoc. 16(5), 400-411 (2015)

61. E. Aadland, R. Jepsen, J.R. Andersen, S.A. Anderssen, Differences in fat loss in response to physical activity among severely obese men and women. J. Rehabil. Med. 46(4), 363-369 (2014)

62. T.A. Astorino, M.M. Schubert, Individual responses to completion of short-term and chronic interval training: a retrospective study. PLoS ONE 9(5), e97638 (2014)

63. K.M. Huffman, T.R. Koves, M.J. Hubal, H. Abouassi, N. Beri, L.A. Bateman, R.D. Stevens, O.R. Ilkayeva, E.P. Hoffman, D.M. Muoio, W.E. Kraus, Metabolite signatures of exercise training in human skeletal muscle relate to mitochondrial remodelling and cardiometabolic fitness. Diabetologia 57(11), 2282-2295 (2014)

64. P.B. Laursen, D.G. Jenkins, The scientific basis for high-intensity interval training: optimising training programmes and maximising performance in highly trained endurance athletes. Sports Med. Auckl. NZ 32(1), 53-73 (2002)

65. J.S. Ramos, L.C. Dalleck, A.E. Tjonna, K.S. Beetham, J.S. Coombes, The impact of high-intensity interval training versus moderate-intensity continuous training on vascular function: a systematic review and meta-analysis. Sports Med. Auckl. NZ 45(5), 679-692 (2015)
66. K.S. Weston, U. Wisløff, J.S. Coombes, High-intensity interval training in patients with lifestyle-induced cardiometabolic disease: a systematic review and meta-analysis. Br. J. Sports Med. 48(16), 1227-1234 (2014)

67. J.A. Babraj, N.B.J. Vollaard, C. Keast, F.M. Guppy, G. Cottrell, J.A. Timmons, Extremely short duration high intensity interval training substantially improves insulin action in young healthy males. BMC Endocr. Disord. 9, 3 (2009)

68. R.S. Metcalfe, J.A. Babraj, S.G. Fawkner, N.B.J. Vollaard, Towards the minimal amount of exercise for improving metabolic health: beneficial effects of reduced-exertion high-intensity interval training. Eur. J. Appl. Physiol. 112(7), 2767-2775 (2012)

69. L. Karavirta, K. Häkkinen, A. Kauhanen, A. Arija-Blázquez, E. Sillanpää, N. Rinkinen, A. Häkkinen, Individual responses to combined endurance and strength training in older adults. Med. Sci. Sports Exerc. 43(3), 484-490 (2011)

70. T.W. Buford, M.D. Roberts, T.S. Church, Toward exercise as personalized medicine. Sports Med. Auckl. NZ 43(3), 157-165 (2013)

71. P. Weyrich, N. Stefan, H.-U. Häring, M. Laakso, A. Fritsche, Effect of genotype on success of lifestyle intervention in subjects at risk for type 2 diabetes. J. Mol. Med. Berl. Ger. 85(2), 107-117 (2007)

72. C. Thamer, J. Machann, N. Stefan, M. Haap, S. Schäfer, S. Brenner, K. Kantartzis, C. Claussen, F. Schick, H. Haring, A. Fritsche, High visceral fat mass and high liver fat are associated with resistance to lifestyle intervention. Obes. Silver Spring Md 15(2), 531-538 (2007)

73. T.N. Mann, R.P. Lamberts, M.I. Lambert, High responders and low responders: factors associated with individual variation in response to standardized training. Sports Med. Auckl. NZ 44(8), 1113-1124 (2014)

74. D.E. Laaksonen, J. Lindström, T.A. Lakka, J.G. Eriksson, L. Niskanen, K. Wikström, S. Aunola, S. Keinänen-Kiukaanniemi, M. Laakso, T.T. Valle, P. Ilanne-Parikka, A. Louheranta, H. Hämäläinen, M. Rastas, V. Salminen, Z. Cepaitis, M. Hakumäki, H. Kaikkonen, P. Härkönen, J. Sundvall, J. Tuomilehto, M. Uusitupa, Finnish Diabetes Prevention Study, Physical activity in the prevention of type 2 diabetes: the Finnish diabetes prevention study. Diabetes 54(1), 158-165 (2005)

75. C.S. Bickel, J.M. Cross, M.M. Bamman, Exercise dosing to retain resistance training adaptations in young and older adults. Med. Sci. Sports Exerc. 43(7), 1177-1187 (2011)

76. S.B. Sisson, P.T. Katzmarzyk, C.P. Earnest, C. Bouchard, S.N. Blair, T.S. Church, Volume of exercise and fitness nonresponse in sedentary, postmenopausal women. Med. Sci. Sports Exerc. 41(3), 539-545 (2009)

77. N.M. Johannsen, L.M. Sparks, Z. Zhang, C.P. Earnest, S.R. Smith, T.S. Church, E. Ravussin, Determinants of the changes in glycemic control with exercise training in type 2 diabetes: a randomized trial. PLoS ONE 8(6), e62973 (2013)

78. T. Kasumov, T.P.J. Solomon, C. Hwang, H. Huang, J.M. Haus, R. Zhang, J.P. Kirwan, Improved insulin sensitivity after exercise training is linked to reduced plasma C14:0 ceramide in obesity and type 2 diabetes. Obes. Silver Spring Md 23(7), 1414-1421 (2015)

79. D.N. Miranda, D.K. Coletta, L.J. Mandarino, G.Q. Shaibi, Increases in insulin sensitivity among obese youth are associated with gene expression changes in whole blood. Obes. Silver Spring Md 22(5), 1337-1344 (2014)

80. A. E. Kitabchi, M. Temprosa, W. C. Knowler, S. E. Kahn, S. E. Fowler, S. M. Haffner, R. Andres, C. Saudek, S. L. Edelstein, R. Arakaki, M. B. Murphy, H. Shamoon, Diabetes Prevention Program Research Group, Role of insulin secretion and sensitivity in the evolution of type 2 diabetes in the diabetes 
prevention program: effects of lifestyle intervention and metformin. Diabetes 54(8), 2404-2414 (2005)

81. N. Stefan, A.M. Hennige, H. Staiger, J. Machann, F. Schick, S.M. Kröber, F. Machicao, A. Fritsche, H.-U. Häring, Alpha2Heremans-Schmid glycoprotein/fetuin-A is associated with insulin resistance and fat accumulation in the liver in humans. Diabetes Care 29(4), 853-857 (2006)

82. N. Stefan, H. Staiger, R. Wagner, J. Machann, F. Schick, H.-U. Häring, A. Fritsche, A high-risk phenotype associates with reduced improvement in glycaemia during a lifestyle intervention in prediabetes. Diabetologia Sep. (2015)

83. J.O. Holloszy, J. Schultz, J. Kusnierkiewicz, J.M. Hagberg, A.A. Ehsani, Effects of exercise on glucose tolerance and insulin resistance. Brief review and some preliminary results. Acta Med. Scand. Suppl. 711, 55-65 (1986)

84. L.C. Alvarez, R. Ramírez-Campillo, O.M. Flores, C. HenríquezOlguín, J.C. Campos, V. Carrasco, S.C. Martínez, C. CelisMorales, Metabolic response to high intensity exercise training in sedentary hyperglycemic and hypercholesterolemic women. Rev. Médica Chile, 141(10), 1293-1299 (2013)

85. J.S. Hansen, X. Zhao, M. Irmler, X. Liu, M. Hoene, M. Scheler, Y. Li, J. Beckers, M. Hrabĕ de Angelis, H.-U. Häring, B.K. Pedersen, R. Lehmann, G. Xu, P. Plomgaard, C. Weigert, Type 2 diabetes alters metabolic and transcriptional signatures of glucose and amino acid metabolism during exercise and recovery. Diabetologia 58(8), 1845-1854 (2015)

86. M. Trovati, Q. Carta, F. Cavalot, S. Vitali, C. Banaudi, P.G. Lucchina, F. Fiocchi, G. Emanuelli, G. Lenti, Influence of physical training on blood glucose control, glucose tolerance, insulin secretion, and insulin action in non-insulin-dependent diabetic patients. Diabetes Care 7(5), 416-420 (1984)

87. K. Kantartzis, J. Machann, F. Schick, K. Rittig, F. Machicao, A. Fritsche, H.-U. Häring, N. Stefan, Effects of a lifestyle intervention in metabolically benign and malign obesity. Diabetologia 54(4), 864-868 (2011)

88. Y.C. Klimentidis, J.W. Bea, T. Lohman, P.-S. Hsieh, S. Going, Z. Chen, High genetic risk individuals benefit less from resistance exercise intervention. Int. J. Obes. 2005, Apr. (2015)

89. P. Hamel, J.A. Simoneau, G. Lortie, M.R. Boulay, C. Bouchard, Heredity and muscle adaptation to endurance training. Med. Sci. Sports Exerc. 18(6), 690-696 (1986)

90. L. Pérusse, J. Gagnon, M.A. Province, D.C. Rao, J.H. Wilmore, A.S. Leon, C. Bouchard, J.S. Skinner, Familial aggregation of submaximal aerobic performance in the HERITAGE Family study. Med. Sci. Sports Exerc. 33(4), 597-604 (2001)

91. I. Peter, G.D. Papandonatos, L.M. Belalcazar, Y. Yang, B. Erar, J.M. Jakicic, J.L. Unick, A. Balasubramanyam, E.W. Lipkin, L.M. Delahanty, L.E. Wagenknecht, R.R. Wing, J.M. McCaffery, G.S. Huggins, Look AHEAD Research Group, Genetic modifiers of cardiorespiratory fitness response to lifestyle intervention. Med. Sci. Sports Exerc. 46(2), 302-311 (2014)

92. L.S. Pescatello, J.M. Devaney, M.J. Hubal, P.D. Thompson, E.P. Hoffman, Highlights from the functional single nucleotide polymorphisms associated with human muscle size and strength or FAMuSS study. BioMed Res. Int. 2013, 643575 (2013)

93. J.A. Timmons, S. Knudsen, T. Rankinen, L.G. Koch, M. Sarzynski, T. Jensen, P. Keller, C. Scheele, N.B.J. Vollaard, S. Nielsen, T. Akerström, O.A. MacDougald, E. Jansson, P.L. Greenhaff, M.A. Tarnopolsky, L.J.C. van Loon, B.K. Pedersen, C.J. Sundberg, C. Wahlestedt, S.L. Britton, C. Bouchard, Using molecular classification to predict gains in maximal aerobic capacity following endurance exercise training in humans. J. Appl. Physiol. Bethesda Md 1985, 108(6), 1487-1496, Jun. (2010)

94. C. Bouchard, Genomic predictors of trainability. Exp. Physiol. 97(3), 347-352 (2012)
95. G. Kacerovsky-Bielesz, M. Kacerovsky, M. Chmelik, M. Farukuoye, C. Ling, R. Pokan, H. Tschan, J. Szendroedi, A.I. Schmid, S. Gruber, C. Herder, M. Wolzt, E. Moser, G. Pacini, G. Smekal, L. Groop, M. Roden, A single nucleotide polymorphism associates with the response of muscle ATP synthesis to long-term exercise training in relatives of type 2 diabetic humans. Diabetes Care 35(2), 350-357 (2012)

96. V.R.A. Vargas, S.L. Bonatto, F.E. Macagnan, A.M.P. Feoli, C.S. Alho, N.D.V. Santos, V.M. Schmitt, Influence of the 48867A > C (Asp358Ala) IL6R polymorphism on response to a lifestyle modification intervention in individuals with metabolic syndrome. Genet. Mol. Res. GMR 12(3), 3983-3991 (2013)

97. T. A. Lakka, T. Rankinen, S. J. Weisnagel, Y. C. Chagnon, T. Rice, A. S. Leon, J. S. Skinner, J. H. Wilmore, D. C. Rao, C. Bouchard, Heritage Family Study, A quantitative trait locus on $7 \mathrm{q} 31$ for the changes in plasma insulin in response to exercise training: the HERITAGE Family Study. Diabetes 52(6), 1583-1587 (2003)

98. M.L.R. Curti, M.M. Rogero, V.T. Baltar, C.R. Barros, A. Siqueira-Catania, S.R.G. Ferreira, FTO T/A and peroxisome proliferator-activated receptor- $\gamma$ Pro12Ala polymorphisms but not ApoA1-75 are associated with better response to lifestyle intervention in Brazilians at high cardiometabolic risk. Metab. Syndr. Relat. Disord. 11(3), 169-176 (2013)

99. N. Stefan, F. Machicao, H. Staiger, J. Machann, F. Schick, O. Tschritter, C. Spieth, C. Weigert, A. Fritsche, M. Stumvoll, H.U. Häring, Polymorphisms in the gene encoding adiponectin receptor 1 are associated with insulin resistance and high liver fat. Diabetologia 48(11), 2282-2291 (2005)

100. C. Thamer, J. Machann, N. Stefan, S.A. Schäfer, F. Machicao, H. Staiger, M. Laakso, M. Böttcher, C. Claussen, F. Schick, A. Fritsche, H.-U. Haring, Variations in PPARD determine the change in body composition during lifestyle intervention: a whole-body magnetic resonance study. J. Clin. Endocrinol. Metab. 93(4), 1497-1500 (2008)

101. N. Stefan, C. Thamer, H. Staiger, F. Machicao, J. Machann, F. Schick, C. Venter, A. Niess, M. Laakso, A. Fritsche, H.-U. Häring, Genetic variations in PPARD and PPARGC1A determine mitochondrial function and change in aerobic physical fitness and insulin sensitivity during lifestyle intervention. J. Clin. Endocrinol. Metab. 92(5), 1827-1833 (2007)

102. A. Haupt, C. Thamer, M. Heni, C. Ketterer, J. Machann, F. Schick, F. Machicao, N. Stefan, C.D. Claussen, H.-U. Häring, A. Fritsche, H. Staiger, Gene variants of TCF7L2 influence weight loss and body composition during lifestyle intervention in a population at risk for type 2 diabetes. Diabetes 59(3), 747-750 (2010)

103. P. Weyrich, F. Machicao, J. Reinhardt, J. Machann, F. Schick, O. Tschritter, N. Stefan, A. Fritsche, H.-U. Häring, SIRT1 genetic variants associate with the metabolic response of Caucasians to a controlled lifestyle intervention-the TULIP study. BMC Med. Genet. 9, 100 (2008)

104. J. Denham, F.Z. Marques, B.J. O'Brien, F.J. Charchar, Exercise: putting action into our epigenome. Sports Med. Auckl. NZ 44(2), 189-209 (2014)

105. M.D. Nitert, T. Dayeh, P. Volkov, T. Elgzyri, E. Hall, E. Nilsson, B.T. Yang, S. Lang, H. Parikh, Y. Wessman, H. Weishaupt, J. Attema, M. Abels, N. Wierup, P. Almgren, P.-A. Jansson, T. Rönn, O. Hansson, K.-F. Eriksson, L. Groop, C. Ling, Impact of an exercise intervention on DNA methylation in skeletal muscle from first-degree relatives of patients with type 2 diabetes. Diabetes 61(12), 3322-3332 (2012)

106. M.E. Lindholm, F. Marabita, D. Gomez-Cabrero, H. Rundqvist, T.J. Ekström, J. Tegnér, C.J. Sundberg, An integrative analysis reveals coordinated reprogramming of the epigenome and the transcriptome in human skeletal muscle after training. Epigenetics 9(12), 1557-1569 (2014) 
107. R. Barrès, J. Yan, B. Egan, J.T. Treebak, M. Rasmussen, T. Fritz, K. Caidahl, A. Krook, D.J. O’Gorman, J.R. Zierath, Acute exercise remodels promoter methylation in human skeletal muscle. Cell Metab. 15(3), 405-411 (2012)

108. S.L. McGee, E. Fairlie, A.P. Garnham, M. Hargreaves, Exercise-induced histone modifications in human skeletal muscle. J. Physiol. 587(Pt 24), 5951-5958 (2009)

109. S. Nielsen, T. Ảkerström, A. Rinnov, C. Yfanti, C. Scheele, B.K. Pedersen, M.J. Laye, The miRNA plasma signature in response to acute aerobic exercise and endurance training. PLoS ONE 9(2), e87308 (2014)

110. S. Nielsen, C. Scheele, C. Yfanti, T. Akerström, A.R. Nielsen, B.K. Pedersen, M.J. Laye, M. Laye, Muscle specific microRNAs are regulated by endurance exercise in human skeletal muscle. J. Physiol. 588(Pt 20), 4029-4037 (2010)

111. D. de Gonzalo-Calvo, A. Dávalos, A. Montero, Á. GarcíaGonzález, I. Tyshkovska, A. González-Medina, S.M.A. Soares, P. Martínez-Camblor, P. Casas-Agustench, M. Rabadán, Á.E. Díaz-Martínez, N. Úbeda, E. Iglesias-Gutiérrez, Circulating inflammatory miRNA signature in response to different doses of aerobic exercise. J. Appl. Physiol. Bethesda Md 1985 119(2), 124-134 (2015)

112. C.S. McLean, C. Mielke, J.M. Cordova, P.R. Langlais, B. Bowen, D. Miranda, D.K. Coletta, L.J. Mandarino, Gene and MicroRNA expression responses to exercise; relationship with insulin sensitivity. PLoS ONE 10(5), e0127089 (2015)

113. P.K. Davidsen, I.J. Gallagher, J.W. Hartman, M.A. Tarnopolsky, F. Dela, J.W. Helge, J.A. Timmons, S.M. Phillips, High responders to resistance exercise training demonstrate differential regulation of skeletal muscle microRNA expression. J. Appl. Physiol. Bethesda Md 1985 110(2), 309-317 (2011)

114. R.A. DeFronzo, E. Ferrannini, Y. Sato, P. Felig, J. Wahren, Synergistic interaction between exercise and insulin on peripheral glucose uptake. J. Clin. Invest. 68(6), 1468-1474 (1981)

115. J.A. Hawley, S.J. Lessard, Exercise training-induced improvements in insulin action. Acta Physiol. Oxf. Engl. 192(1), 127-135 (2008)

116. B. Egan, J.R. Zierath, Exercise metabolism and the molecular regulation of skeletal muscle adaptation. Cell Metab. 17(2), 162-184 (2013)

117. S.J. Prior, J.B. Blumenthal, L.I. Katzel, A.P. Goldberg, A.S. Ryan, Increased skeletal muscle capillarization after aerobic exercise training and weight loss improves insulin sensitivity in adults with IGT. Diabetes Care 37(5), 1469-1475 (2014)

118. E.A. Richter, M. Hargreaves, Exercise, GLUT4, and skeletal muscle glucose uptake. Physiol. Rev. 93(3), 993-1017 (2013)

119. J.F.P. Wojtaszewski, E.A. Richter, Effects of acute exercise and training on insulin action and sensitivity: focus on molecular mechanisms in muscle. Essays Biochem. 42, 31-46 (2006)

120. A.S. Deshmukh, J.A. Hawley, J.R. Zierath, Exercise-induced phospho-proteins in skeletal muscle. Int. J. Obes. 2005 32(Suppl 4), S18-S23 (2008)

121. B. Kiens, T.J. Alsted, J. Jeppesen, Factors regulating fat oxidation in human skeletal muscle. Obes. Rev. Off. J. Int. Assoc. Study Obes. 12(10), 852-858 (2011)

122. A. Thalacker-Mercer, M. Stec, X. Cui, J. Cross, S. Windham, M. Bamman, Cluster analysis reveals differential transcript profiles associated with resistance training-induced human skeletal muscle hypertrophy. Physiol. Genomics 45(12), 499-507 (2013)

123. D.M. Huffman, N. Barzilai, Contribution of adipose tissue to health span and longevity. Interdiscip. Top. Gerontol. 37, 1-19 (2010)

124. E.E. Kershaw, J.S. Flier, Adipose tissue as an endocrine organ. J. Clin. Endocrinol. Metab. 89(6), 2548-2556 (2004)

125. J.H. Goedecke, L.K. Micklesfield, The effect of exercise on obesity, body fat distribution and risk for type 2 diabetes. Med. Sport Sci. 60, 82-93 (2014)
126. J. Tuomilehto, J. Lindström, J. G. Eriksson, T. T. Valle, H. Hämäläinen, P. Ilanne-Parikka, S. Keinänen-Kiukaanniemi, M. Laakso, A. Louheranta, M. Rastas, V. Salminen, M. Uusitupa, Finnish Diabetes Prevention Study Group, Prevention of type 2 diabetes mellitus by changes in lifestyle among subjects with impaired glucose tolerance. N. Engl. J. Med. 344(18), 1343-1350 (2001)

127. W. C. Knowler, E. Barrett-Connor, S. E. Fowler, R. F. Hamman, J. M. Lachin, E. A. Walker, D. M. Nathan, Diabetes Prevention Program Research Group, Reduction in the incidence of type 2 diabetes with lifestyle intervention or metformin. N. Engl. J. Med. 346(6), 393-403 (2002)

128. T. Christiansen, S.K. Paulsen, J.M. Bruun, S.B. Pedersen, B. Richelsen, Exercise training versus diet-induced weight-loss on metabolic risk factors and inflammatory markers in obese subjects: a 12-week randomized intervention study. Am. J. Physiol. Endocrinol. Metab. 298(4), E824-831 (2010)

129. K.I. Stanford, R.J.W. Middelbeek, K.L. Townsend, M.-Y. Lee, H. Takahashi, K. So, K.M. Hitchcox, K.R. Markan, K. Hellbach, M.F. Hirshman, Y.-H. Tseng, L.J. Goodyear, A novel role for subcutaneous adipose tissue in exercise-induced improvements in glucose homeostasis. Diabetes 64(6), 2002-2014 (2015)

130. E. Trevellin, M. Scorzeto, M. Olivieri, M. Granzotto, A. Valerio, L. Tedesco, R. Fabris, R. Serra, M. Quarta, C. Reggiani, E. Nisoli, R. Vettor, Exercise training induces mitochondrial biogenesis and glucose uptake in subcutaneous adipose tissue through eNOSdependent mechanisms. Diabetes 63(8), 2800-2811 (2014)

131. Y.-M. Park, M. Myers, V.J. Vieira-Potter, Adipose tissue inflammation and metabolic dysfunction: role of exercise. Mo. Med. 111(1), 65-72 (2014)

132. T. Sakurai, J. Ogasawara, T. Kizaki, S. Sato, Y. Ishibashi, M. Takahashi, O. Kobayashi, S. Oh-Ishi, J. Nagasawa, K. Takahashi, H. Ishida, T. Izawa, H. Ohno, The effects of exercise training on obesity-induced dysregulated expression of adipokines in white adipose tissue. Int. J. Endocrinol. 2013, 801743 (2013)

133. D.A. Bernlohr, Exercise and mitochondrial function in adipose biology: all roads lead to NO. Diabetes 63(8), 2606-2608 (2014)

134. E. De Filippis, G. Alvarez, R. Berria, K. Cusi, S. Everman, C. Meyer, L.J. Mandarino, Insulin-resistant muscle is exercise resistant: evidence for reduced response of nuclear-encoded mitochondrial genes to exercise. Am. J. Physiol. Endocrinol. Metab. 294(3), E607-614 (2008)

135. T. Rönn, P. Volkov, A. Tornberg, T. Elgzyri, O. Hansson, K.-F. Eriksson, L. Groop, C. Ling, Extensive changes in the transcriptional profile of human adipose tissue including genes involved in oxidative phosphorylation after a 6-month exercise intervention. Acta Physiol. Oxf. Engl. 211(1), 188-200 (2014)

136. K. Ruschke, L. Fishbein, A. Dietrich, N. Klöting, A. Tönjes, A. Oberbach, M. Fasshauer, J. Jenkner, M.R. Schön, M. Stumvoll, M. Blüher, C.S. Mantzoros, Gene expression of PPARgamma and PGC-1alpha in human omental and subcutaneous adipose tissues is related to insulin resistance markers and mediates beneficial effects of physical training. Eur. J. Endocrinol. Eur. Fed. Endocr. Soc. 162(3), 515-523 (2010)

137. R.G. Walton, B.S. Finlin, J. Mula, D.E. Long, B. Zhu, C.S. Fry, P.M. Westgate, J.D. Lee, T. Bennett, P.A. Kern, C.A. Peterson, Insulin-resistant subjects have normal angiogenic response to aerobic exercise training in skeletal muscle, but not in adipose tissue. Physiol. Rep. 3(6), Jun. (2015)

138. E. Clementi, E. Nisoli, Nitric oxide and mitochondrial biogenesis: a key to long-term regulation of cellular metabolism. Comp. Biochem. Physiol. A: Mol. Integr. Physiol. 142(2), 102-110 (2005)

139. J.R. Ruiz, B. Martinez-Tellez, G. Sanchez-Delgado, C.M. Aguilera, A. Gil, Regulation of energy balance by brown adipose tissue: at least three potential roles for physical activity. Br. J. Sports Med. 49(15), 972-973 (2015) 
140. P.C. Dinas, A. Nikaki, A.Z. Jamurtas, V. Prassopoulos, R. Efthymiadou, Y. Koutedakis, P. Georgoulias, A.D. Flouris, Association between habitual physical activity and brown adipose tissue activity in individuals undergoing PET-CT scan. Clin. Endocrinol. (Oxf.) 82(1), 147-154 (2015)

141. C. Scheele, Adipose adaptation to exercise training -increased metabolic rate but no signs of browning. Acta Physiol. Oxf. Engl. 211(1), 11-12 (2014)

142. F. Norheim, T.M. Langleite, M. Hjorth, T. Holen, A. Kielland, H.K. Stadheim, H.L. Gulseth, K.I. Birkeland, J. Jensen, C.A. Drevon, The effects of acute and chronic exercise on PGC-1 $\alpha$, irisin and browning of subcutaneous adipose tissue in humans. FEBS J. 281(3), 739-749 (2014)

143. G. Sanchez-Delgado, B. Martinez-Tellez, J. Olza, C.M. Aguilera, Á. Gil, J.R. Ruiz, Role of exercise in the activation of brown adipose tissue. Ann. Nutr. Metab. 67(1), 21-32 (2015)

144. P. Boström, J. Wu, M.P. Jedrychowski, A. Korde, L. Ye, J.C. Lo, K.A. Rasbach, E.A. Boström, J.H. Choi, J.Z. Long, S. Kajimura, M.C. Zingaretti, B.F. Vind, H. Tu, S. Cinti, K. Højlund, S.P. Gygi, B.M. Spiegelman, A PGC1- $\alpha$-dependent myokine that drives brown-fat-like development of white fat and thermogenesis. Nature 481(7382), 463-468 (2012)

145. J.A. Timmons, K. Baar, P.K. Davidsen, P.J. Atherton, Is irisin a human exercise gene? Nature 488(7413), E9-E10; discussion E10-E11 (2012)

146. S. Raschke, M. Elsen, H. Gassenhuber, M. Sommerfeld, U. Schwahn, B. Brockmann, R. Jung, U. Wisløff, A.E. Tjønna, T. Raastad, J. Hallén, F. Norheim, C.A. Drevon, T. Romacho, K. Eckardt, J. Eckel, Evidence against a beneficial effect of irisin in humans. PLoS ONE 8(9), e73680 (2013)

147. H. Staiger, A. Böhm, M. Scheler, L. Berti, J. Machann, F. Schick, F. Machicao, A. Fritsche, N. Stefan, C. Weigert, A. Krook, H.-U. Häring, M.H. de Angelis, Common genetic variation in the human FNDC5 locus, encoding the novel musclederived 'browning' factor irisin, determines insulin sensitivity. PLoS ONE 8(4), e61903 (2013)

148. E. Albrecht, F. Norheim, B. Thiede, T. Holen, T. Ohashi, L. Schering, S. Lee, J. Brenmoehl, S. Thomas, C.A. Drevon, H.P. Erickson, S. Maak, Irisin - a myth rather than an exercise-inducible myokine. Sci. Rep. 5, 8889 (2015)

149. M. Snel, J.T. Jonker, J. Schoones, H. Lamb, A. de Roos, H. Pijl, J.W.A. Smit, A.E. Meinders, I.M. Jazet, Ectopic fat and insulin resistance: pathophysiology and effect of diet and lifestyle interventions. Int. J. Endocrinol. 2012, 983814 (2012)

150. E. Yoshimura, H. Kumahara, T. Tobina, M. Ayabe, S. Matono, K. Anzai, Y. Higaki, A. Kiyonaga, H. Tanaka, A 12-week aerobic exercise program without energy restriction improves intrahepatic fat, liver function and atherosclerosis-related factors. Obes. Res. Clin. Pract. 5(3), e169-266 (2011)

151. K. Shah, A. Stufflebam, T.N. Hilton, D.R. Sinacore, S. Klein, D.T. Villareal, Diet and exercise interventions reduce intrahepatic fat content and improve insulin sensitivity in obese older adults. Obes. Silver Spring Md 17(12), 2162-2168 (2009)

152. M. Tiikkainen, R. Bergholm, S. Vehkavaara, A. Rissanen, A.-M. Häkkinen, M. Tamminen, K. Teramo, H. Yki-Järvinen, Effects of identical weight loss on body composition and features of insulin resistance in obese women with high and low liver fat content. Diabetes 52(3), 701-707 (2003)

153. A. Egger, R. Kreis, S. Allemann, C. Stettler, P. Diem, T. Buehler, C. Boesch, E.R. Christ, The effect of aerobic exercise on intrahepatocellular and intramyocellular lipids in healthy subjects. PLoS ONE 8(8), e70865 (2013)

154. M. Hoene, R. Lehmann, A.M. Hennige, A.K. Pohl, H.U. Häring, E.D. Schleicher, C. Weigert, Acute regulation of metabolic genes and insulin receptor substrates in the liver of mice by one single bout of treadmill exercise. J. Physiol. 587(Pt 1), 241-252 (2009)
155. M. Hoene, H. Franken, L. Fritsche, R. Lehmann, A.K. Pohl, H.U. Häring, A. Zell, E.D. Schleicher, C. Weigert, Activation of the mitogen-activated protein kinase (MAPK) signalling pathway in the liver of mice is related to plasma glucose levels after acute exercise. Diabetologia 53(6), 1131-1141 (2010)

156. J.S. Hansen, J.O. Clemmesen, N.H. Secher, M. Hoene, A. Drescher, C. Weigert, B.K. Pedersen, P. Plomgaard, Glucagonto-insulin ratio is pivotal for splanchnic regulation of FGF-21 in humans. Mol. Metab. 4(8), 551-560 (2015)

157. A. Kharitonenkov, A.C. Adams, Inventing new medicines: the FGF21 story. Mol. Metab. 3(3), 221-229 (2014)

158. M.P. Mattson, Energy intake and exercise as determinants of brain health and vulnerability to injury and disease. Cell Metab. 16(6), 706-722 (2012)

159. C. Martins, H. Truby, L.M. Morgan, Short-term appetite control in response to a 6-week exercise programme in sedentary volunteers. Br. J. Nutr. 98(4), 834-842 (2007)

160. C. Martins, M.D. Robertson, L.M. Morgan, Effects of exercise and restrained eating behaviour on appetite control. Proc. Nutr. Soc. 67(1), 28-41 (2008)

161. O. Tschritter, H. Preissl, A.M. Hennige, T. Sartorius, K.T. Stingl, M. Heni, C. Ketterer, N. Stefan, J. Machann, E. Schleicher, A. Fritsche, H.-U. Häring, High cerebral insulin sensitivity is associated with loss of body fat during lifestyle intervention. Diabetologia 55(1), 175-182 (2012)

162. M. Heni, S. Kullmann, C. Ketterer, M. Guthoff, K. Linder, R. Wagner, K.T. Stingl, R. Veit, H. Staiger, H.-U. Häring, H. Preissl, A. Fritsche, Nasal insulin changes peripheral insulin sensitivity simultaneously with altered activity in homeostatic and reward-related human brain regions. Diabetologia 55(6), 1773-1782 (2012)

163. M. Heni, R. Wagner, S. Kullmann, R. Veit, H. Mat Husin, K. Linder, C. Benkendorff, A. Peter, N. Stefan, H.-U. Häring, H. Preissl, A. Fritsche, Central insulin administration improves whole-body insulin sensitivity via hypothalamus and parasympathetic outputs in men. Diabetes 63(12), 4083-4088 (2014)

164. A. Kleinridders, H.A. Ferris, W. Cai, C.R. Kahn, Insulin action in brain regulates systemic metabolism and brain function. Diabetes 63(7), 2232-2243 (2014)

165. V.J. Vieira-Potter, Inflammation and macrophage modulation in adipose tissues. Cell. Microbiol. 16(10), 1484-1492 (2014)

166. B.K. Pedersen, M.A. Febbraio, Muscles, exercise and obesity: skeletal muscle as a secretory organ. Nat. Rev. Endocrinol. 8(8), 457-465 (2012)

167. N. Duarte, I.C. Coelho, R.S. Patarrão, J.I. Almeida, C. PenhaGonçalves, M.P. Macedo, How Inflammation Impinges on NAFLD: a role for Kupffer cells. BioMed Res. Int. 2015, 984578 (2015)

168. M. Gleeson, N.C. Bishop, D.J. Stensel, M.R. Lindley, S.S. Mastana, M.A. Nimmo, The anti-inflammatory effects of exercise: mechanisms and implications for the prevention and treatment of disease. Nat. Rev. Immunol. 11(9), 607-615 (2011)

169. A.M.W. Petersen, B.K. Pedersen, The anti-inflammatory effect of exercise. J. Appl. Physiol. Bethesda Md 1985 98(4), 1154-1162 (2005)

170. E.R. Ropelle, M.B. Flores, D.E. Cintra, G.Z. Rocha, J.R. Pauli, J. Morari, C.T. de Souza, J.C. Moraes, P.O. Prada, D. Guadagnini, R.M. Marin, A.G. Oliveira, T.M. Augusto, H.F. Carvalho, L.A. Velloso, M.J.A. Saad, J.B.C. Carvalheira, IL-6 and IL-10 anti-inflammatory activity links exercise to hypothalamic insulin and leptin sensitivity through IKKbeta and ER stress inhibition. PLoS Biol. 8(8), 2010

171. G. Paulsen, U.R. Mikkelsen, T. Raastad, J.M. Peake, Leucocytes, cytokines and satellite cells: what role do they play in muscle damage and regeneration following eccentric exercise? Exerc. Immunol. Rev. 18, 42-97 (2012) 